\title{
HUBUNGAN KEMAMPUAN MEMBEDAKAN PARAGRAF DEDUKTIF \\ DAN PARAGRAF INDUKTIF DENGAN KEMAMPUAN MENULIS \\ BERITA SISWA KELAS X MADRASAH ALIYAH \\ MUHAMMADIYAH 1 MEDAN TAHUN \\ PEMBELAJARAN 2016/2017
}

\author{
Oleh \\ Nirmala Sari Siregar (nirmalasiregar034@gmail.com) \\ Fitriani Lubis, S.Pd., M.Pd.
}

\begin{abstract}
ABSTRAK
Penelitian ini bertujuan untuk mengetahui Hubungan Kemampuan Membedakan Paragraf Deduktif dan Paragraf Induktif dengan Kemampuan Menulis Berita oleh siswa kelas X Madrasah Aliyah Muhammadiyah 1 Medan tahun pembelajaran 2016/2017. Penelitian ini menggunakan sumber data adalah tes pilihan ganda sebanyak 20 soal dan tes esai. Populasi penelitian ini berjumlah 51 siswa. Dalam penelitian ini, populasi terdiri dari 2 kelas. Untuk menentukan sampel, peneliti menggunakan teknik sampel populasi dengan menggunakan seluruh jumlah populasi untuk dijadikan sampel. Metode yang digunakan dalam penelitian ini adalah korelasional bertujuan untuk menemukan ada tidaknya hubungan dan apabila ada, berapa eratnya hubungan serta berarti atau tidaknya hubungan itu". Jadi, analisis korelasional yang digunakan dalam pengolahan data dalam penelitian ini bertujuan untuk melihat hubungan antara dua variabel, hubungan kemampuan membedakan paragraf deduktif dan paragraf induktif dengan kemampuan menulis berita. Hasil penelitian ini menunjukkan bahwa kemampuan siswa dalam membedakan paragraf deduktif dan paragraf induktif termasuk kategori baik dengan nilai rata-rata 64,75 , sedangkan kemampuan siswa dalam menulis berita termasuk dalam kategori baik dengan nilai rata-rata yang diperoleh siswa adalah 68,3. Selanjutnya Sesuai dengan kriteria pengujian dengan uji ' $r$ ' maka hubungan variabel $\mathrm{X}$ dengan $\mathrm{Y}$ pada penelitian ini merupakan korelasi yang signifikan, sehingga semakin baik kemampuan membedakan paragraf deduktif dan paragraf induktif oleh siswa maka semakin baik pula kemampuan siswa kelas $X$ Madrasah Aliyah Muhammadiyah 1 Medan tahun pembelajaran 2016/2017 dalam menulis berita.
\end{abstract}

Kata Kunci : Paragraf Deduktif, Paragraf Induktif, Menulis Berita

\section{PENDAHULUAN}

Penguasaan kemampuan berbahasa Indonesia sangat penting sebagai alat komunikasi, baik secara lisan maupun tulisan. Kemampuan berbahasa ini harus dibina dan 
dikembangkan sejak dini kepada siswa. Salah satu wujud pembinaan kemampuan siswa dalam berbahasa adalah dengan menerapkan pengajaran bahasa di tingkat SD,SMP,SMA dan perguruan tinggi. Karena dengan berbahasa siswa dapat menyampaikan gagasan, pikiran dan perasaan kepada mitra tuturnya. keterampilan berbahasa ada empat yaitu menyimak, berbicara, membaca dan menulis. Keempat keterampilan berbahasa tersebut tidak dapat dipisahkan antara yang satu dengan yang lain karena keempat keterampilan berbahasa merupakan satu kesatuan yang utuh. Di antara keempat aspek keterampilan berbahasa terdapat dua aspek yang bersifat aktif. Dua aspek tersebut adalah membaca dan menulis merupakan keterampilan ber`bahasa yang aktif yang sangat penting untuk dikuasai oleh siswa. Karena dengan menguasai dua aspek tersebut, siswa dapat mengembangkan keterampilan yang dapat bermanfaat bagi masa depan. Dari kedua keterampilan tersebut menulis merupakan satu keterampilan yang penting untuk dikuasai. Sanggup Barus (2010:1) mengemukakan bahwa menulis adalah rangkaian kegiatan mengungkapkan dan menyampaikan gagasan atau pikiran dengan bahasa tulis kepada pembaca sehingga pembaca dapat memahaminya.

Dari uraian di atas jelas bahwa keterampilan menulis perlu mendapat perhatian yang sungguh- sungguh karena sebagai aspek kemampuan berbahasa, menulis memang dapat dikuasai oleh siapa saja yang memiliki kemampuan intelektual yang memadai. Namun berbeda dengan keterampilan menyimak, berbicara dan menulis yang tidak dikuasai seseorang secara alami. Menulis harus dipelajari dan dilatih secara sungguh-sungguh. Salah satu keterampilan menulis yang diajarkan di SMA adalah menulis berita. Berita adalah peristiwa atau infomasi mengenai sesuatu yang telah atau sedang terjadi. Penyampaian berita ini bisa dilakukan secara lisan yang sering kita dengar dan lihat di televisi, dan secara tulisan yang dapat kita baca di media cetak. 
Menurut Maulsby menegaskan menulis berita didefenisikan sebagai suatu penuturan secara benar dan tidak memihak dari fakta-fakta yang mempunyai arti penting dan baru terjadi yang dapat menarik perhatian para pembaca surat kabar yang memuat berita tersebut. Berita biasanya menyangkut manusia, baik karena keberhasilannya, kegagalannya, kehebatannya atau kebodohannya akan tetapi tidak semua manusia dapat menjadi sumber berita yang dapat menarik perhatian orang. Menulis berita itu tidaklah mudah tetapi memerlukan pengetahuan dan latihan. Agar pemahaman kita mengenai berita lebih jelas dan lebih lengkap, masih perlu di elaborasi mengenai ciri-ciri berita yang baik atau dengan kata lain perlu diberikan ciri penanda suatu kejadian yang dapat diangkat menjadi berita. Berita tidak akan datang dengan sendirinya tetapi harus dicari. Dicari artinya wartawan atau pembawa berita harus memburu berita ke tempat kejadian atau peristiwa yang terjadi. Berita yang baik harus memperhatikan rumus $5 \mathrm{~W}+1 \mathrm{H}$.

Kemampuan dalam menulis berita sangat penting, sehingga pada kelas $\mathrm{X}$ mempelajari Menanggapi siaran atau informasi dari media elektronik (berita) hal ini di tujukan pada KD 1.1 yaitu menuliskan isi siaran radio / televisi dalam beberapa kalimat dengan urutan yang runtut dan mudah dipahami dalam berita yang terdapat dalam standar isi Kurikulum Tingkat Satuan Pendidikan (KTSP) mata pelajaran bahasa indonesia untuk kelas $\mathrm{X}$ semester 1.

Berdasarkan pengamatan penulis pada saat melaksanakan PPLT di Madrasah Aliyah Muhammadiyah 1 Medan, peneliti melihat masih rendah kemampuan siswa untuk membedakan paragraf induktif dan paragraf deduktif pada saat menulis berita. Hal ini sejalan dengan hasil wawancara dengan salah satu guru bidang studi Bahasa Indonesia di Madrasah Aliyah Muhammadiyah 1 Medan kelas X Ibu Elisa Safitri yang menjelaskan bahwa kemampuan siswa dalam membedakan paragraf induktif dan paragraf deduktif dalam menulis berita kurang memadai. Terbukti pada saat melaksanakan kegiatan PPLT bahwa sebagian 
siswa tersebut memperoleh nilai di bawah KKM 6,5 Maka siswa tersebut dinyatakan belum memahami materi yang diajarkan, sehingga siswa dalam membedakan paragraf induktif dan paragraf deduktif dalam menulis berita kurang efektif. Di dalam pembelajaran teks berita, siswa mengalami kesulitan pada saat menulis berita. Oleh karena itu, kenyataan dilapangan, keterampilan menulis berita siswa belum maksimal disebabkan karena kurangnya pemahaman tentang unsur-unsur berita.

Tarigan (2008:26), mengemukakan paragraf deduktif adalah paragraf yang kalimat topiknya terletak di awal kalimat. Kalimat topik tersebut dikembangkan dengan pemaparan ataupun deskripsi sampai bagian-bagian kecil sehingga pengertian kalimat topik yang bersifat umum menjadi jelas. Atmazaki (2007), juga menjelaskan bahwa paragraf induktif merupakan proses penarikan kesimpulan berdasarkan keadaan yang bersifat khusus untuk dikristalisasi secara umum. Paragraf induktif ini mutlak diawali dari pernyataan atau fakta khusus yang menuju ke kesimpulan umum, fakta atau pernyataan khusus tersebut merupakan landasan penarikan kesimpulan. Kemampuan membedakan paragraf deduktif dan paragraf induktif merupakan salah satu keterampilan menulis berita yang harus diajarkan di sekolah terutama di Sekolah Menengah Atas (SMA). Kurangnya kemampuan siswa dalam membedakan paragraf induktif dan paragraf deduktif dalam menulis berita.

Peran Guru sangat di tuntut untuk bisa mengajarkan siswa dalam menulis terutama menulis berita, kurangnya kemampuan siswa dalam membedakan paragraf induktif dan paragraf deduktif dengan kemampuan menulis berita membuat guru bahasa Indonesia untuk lebih memperhatikan hal tersebut dan lebih membimbing siswanya agar terampil dalam menulis berita. Setelah semuanya terwujud maka hasil belajar siswa yang diharapkan adalah siswa mampu membedakan paragraf induktif dan paragraf deduktif dalam menulis berita. Pada saat menulis berita siswa tidak memperhatikan sistematika penulisan berita yang baik 
dan benar dan tidak menggunakan unsur-unsur penulisan berita sehingga berita yang siswa tulis tidak sempurna.

Berdasarkan permasalahan yang ditemukan sehingga penulis tertarik untuk melakukan penelitian tentang "Hubungan Kemampuan Membedakan Paragraf Induktif dan Paragraf Deduktif Dengan Kemampuan Menulis Berita Siswa Kelas X Madrasah Aliyah Muhammadiyah 1 Medan Tahun Pembelajaran 2016 / 2017.”

\section{METODE PENELITIAN}

Dalam suatu penelitian, metode memengang peranan yang sangat penting. Hal ini disebabkan karena semua kegiatan yang akan dilakukan dalam penelitian sangat bergantung pada metode yang akan digunakan. Sesuai dengan pendapat Arikunto (2006:22) yang mengatakan "metode penelitian merupakan struktur yang sangat penting, karena berhasil atau tidaknya, ataupun tinggi rendahnya kualitas hasil penelitian sangat ditentukan oleh ketetapan dan memilih metode penelitian." Sesuai dengan tujuan penelitian yaitu untuk melihat hubungan kemampuan membedakan paragraf deduktif dan paragraf induktif dengan kemampuan menulis berita maka penelitian ini termasuk penelitian korelasional. Hal ini sejalan dengan pendapat Arikunto (2006:270) yang menyatakan "Penelitian korelasional bertujuan untuk menemukan ada tidaknya hubungan dan apabila ada, berapa eratnya hubungan serta berarti atau tidaknya hubungan itu". Jadi, analisis korelasional yang digunakan dalam pengolahan data dalam penelitian ini bertujuan untuk melihat hubungan antara dua variabel, hubungan kemampuan membedakan paragraf deduktif dan paragraf induktif dengan kemampuan menulis berita.

\section{HASIL PENELITIAN DAN PEMBAHASAN}

\section{Hasil Penelitian}

\section{Kemampuan membedakan paragraf deduktif dan paragraf induktif}

Paragraf dapat diartikan sebagai kumpulan kalimat yang mengandung satu buah kalimat topik dan beberapa kalimat penjelas yang membentuk satu kesatuan gagasan yang utuh. Berdasarkan hasil dari analisis pengujian hipotesis, terdapat temuan penelitian bahwa hasil pembelajaran membedakan paragraf deduktif dan paragraf induktif dengan menerapkan kemampuan soal-soal yang berisi paragraf deduktif dan paragraf induktif, tergolong dalam katagori cukup dengan nilai rata-rata (mean) yaitu 65, yang mendapatkan nilai sangat baik 1 
orang, atau 1,97\%, nilai baik sebanyak 18 orang atau 35,29\%, dan nilai cukup sebanyak 32 orang atau $62,74 \%$, hal ini dikarenakan sebagian siswa kurang aktif berprestasi dalam proses pembelajaran, siswa kurang paham membedakan antara paragraf deduktif dan paragraf induktif sehingga siswa terlihat jenuh dalam belajar.

Tabel 4.3

Identifikasi Kecendrungan Variabel X

\begin{tabular}{|c|c|c|c|}
\hline Rentangan Nilai & F. Absolut & F. Relatif & Kategori \\
\hline $80-100$ & 1 & $1.97 \%$ & Sangat baik \\
\hline $70-80$ & 18 & $35.29 \%$ & Baik \\
\hline $50-65$ & 32 & $62.74 \%$ & Cukup \\
\hline Jumlah & $\mathbf{5 1}$ & $\mathbf{1 0 0 \%}$ & \\
\hline
\end{tabular}

\section{Kemampuan Menulis Berita}

Kemampuan menulis berita merupakan kemampuan untuk menuangkan gagasannya dengan menggunakan bahasa tulis untuk menceritakan urutan sebuah kejadian. Aktivitas menulis melibatkan beberapa unsur, yaitu: penulis sebagai penyampaian pesan, isi tulisan, saluran atau media, dan pembaca. Sementara itu, sebagian besar orang berpendapat bahwa menulis bukan hal yang mudah sebab diperlukan banyak bekal bagi seseorang untuk keterampilan menulis.

Berdasarkan hasil dari penelitian tentang kemampuan menulis berita, bahwa kemampuan siswa dalam menulis berita tergolong dalam katagori cukup dengan nilai ratarata (mean) yaitu 68,03. yang mendapatkan nilai sangat baik 11 orang, atau 21,57\%, nilai baik sebanyak 22 orang atau 43,14\%, dan nilai cukup sebanyak 18 orang atau 35,29\%, hal tersebut dikarenakan siswa kurang aktif dalam proses pembelajaran.

\section{Tabel 4.5}

Distribusi Frekuensi Nilai Kemampuan Menulis Berita

\begin{tabular}{|c|c|c|c|c|c|}
\hline $\mathbf{X}$ & $\mathbf{F}$ & $\mathbf{F x}$ & $\mathbf{X}$ & $\mathbf{X}^{\mathbf{2}}$ & $\mathbf{F x}^{\mathbf{2}}$ \\
\hline 50 & 4 & 200 & -19.41 & 376.74 & 1506.96 \\
\hline 55 & 4 & 220 & -14.41 & 207.64 & 830.56 \\
\hline 60 & 10 & 600 & -9.41 & 88.54 & 885.4 \\
\hline 65 & 7 & 455 & -4.41 & 19.44 & 136.08 \\
\hline 70 & 7 & 490 & 0.59 & 0.348 & 2.436 \\
\hline 75 & 8 & 600 & 5.59 & 31.24 & 249.92 \\
\hline 80 & 4 & 320 & 10.59 & 112.14 & 448.56 \\
\hline 85 & 7 & 595 & 15.59 & 243.04 & 1701.28 \\
\hline JUMLAH & $\mathbf{5 1}$ & $\mathbf{3 4 8 0}$ & & & $\mathbf{5 7 6 1 . 1 9}$ \\
\hline
\end{tabular}


Jika dilihat tabel distribusi frekuensi di atas, maka data di atas, dapat dikategorikan menjadi tiga kategori yaitu sangat baik, baik dan cukup.

Tabel 4.6

Identifikasi Kecenderungan Variabel Y

\begin{tabular}{|c|c|c|c|}
\hline Rentangan Nilai & F. Absolut & F.Relatif & Kategori \\
\hline $80-100$ & 11 & $21,57 \%$ & Sangat baik \\
\hline $65-75$ & 22 & $43,14 \%$ & Baik \\
\hline $50-60$ & 18 & $35,29 \%$ & Cukup \\
\hline Jumlah & $\mathbf{5 1}$ & $\mathbf{1 0 0 \%}$ & \\
\hline
\end{tabular}

3. Hubungan Kemampuan Membedakan Paragraf Deduktif dan Paragraf Induktif dengan Kemampuan Menulis Berita

Dalam kegiatan membedakan paragraf deduktif dan paragraf induktif, sebagai kisahan suatu kejadian yang menceritakan adanya peristiwa dan tindakan serta waktu yang digunakan dan diceritakan secara kronologis. Pada dasarnya paragraf deduktif kalimat utamanya terletak di awal paragraf. Sedangkan paragraf induktif kalimat utamanya terletak di akhir paragraf. Menulis berita berarti mampu menguasai unsur-unsur yang terdapat di dalam berita tersebut. Menguasai berarti mampu menemukan setiap unsur-unsur yang mendasari sebuah berita. Menentukan unsur-unsur dalam berita yang merupakan prinsip dari $5 \mathrm{~W}+1 \mathrm{H}$ yang merupakan langkah penting yang dilakukan dalam menulis berita. Apa yang terjadi, Siapa yang menjadi tokoh (pelaku atau korban), Kapan peristiwa itu terjadi, Dimana terjadinya, Mengapa peristiwa itu terjadi, dan Bagaimana penyelesaian dari berita tersebut.

Kemampuan siswa dalam membedakan paragraf deduktif dan paragraf induktif memiliki hubungan yang positif dan signifikan dengan kemampuan menulis berita, hal ini dibuktikan dengan koefisien korelasi yang tinggi yaitu 0.380 dan besar sumbangan Kemampuan membedakan paragraf deduktif dan paragraf induktif $38 \%$ terhadap kemampuan menulis berita. Hal ini menunjukkan bahwa kemampuan membedakan paragraf deduktif dan paragraf induktif merupakan alternatif yang perlu diperhatikan dalam meningkatkan kemampuan menulis berita

\section{Pembahasan Hasil Penelitian}




\section{Kemampuan membedakan paragraf deduktif dan paragraf induktif}

Paragraf dapat diartikan sebagai kumpulan kalimat yang mengandung satu buah kalimat topik dan beberapa kalimat penjelas yang membentuk satu kesatuan gagasan yang utuh. Berdasarkan hasil dari analisis pengujian hipotesis, terdapat temuan penelitian bahwa hasil pembelajaran membedakan paragraf deduktif dan paragraf induktif dengan menerapkan kemampuan soal-soal yang berisi paragraf deduktif dan paragraf induktif, tergolong dalam katagori cukup dengan nilai rata-rata (mean) yaitu 65, yang mendapatkan nilai sangat baik 1 orang, atau $1,97 \%$, nilai baik sebanyak 18 orang atau 35,29\%, dan nilai cukup sebanyak 32 orang atau $62,74 \%$, hal ini dikarenakan sebagian siswa kurang aktif berprestasi dalam proses pembelajaran, siswa kurang paham membedakan antara paragraf deduktif dan paragraf induktif sehingga siswa terlihat jenuh dalam belajar.

\section{Kemampuan Menulis Berita}

Kemampuan menulis berita merupakan kemampuan untuk menuangkan gagasannya dengan menggunakan bahasa tulis untuk menceritakan urutan sebuah kejadian. Aktivitas menulis melibatkan beberapa unsur, yaitu: penulis sebagai penyampaian pesan, isi tulisan, saluran atau media, dan pembaca. Sementara itu, sebagian besar orang berpendapat bahwa menulis bukan hal yang mudah sebab diperlukan banyak bekal bagi seseorang untuk keterampilan menulis.

Berdasarkan hasil dari penelitian tentang kemampuan menulis berita, bahwa kemampuan siswa dalam menulis berita tergolong dalam katagori cukup dengan nilai ratarata (mean) yaitu 68,03. yang mendapatkan nilai sangat baik 11 orang, atau $21,57 \%$, nilai baik sebanyak 22 orang atau 43,14\%, dan nilai cukup sebanyak 18 orang atau 35,29\%, hal tersebut dikarenakan siswa kurang aktif dalam proses pembelajaran.

\section{Hubungan Kemampuan Membedakan Paragraf Deduktif dan Paragraf Induktif dengan Kemampuan Menulis Berita}


Dalam kegiatan membedakan paragraf deduktif dan paragraf induktif, sebagai kisahan suatu kejadian yang menceritakan adanya peristiwa dan tindakan serta waktu yang digunakan dan diceritakan secara kronologis. Pada dasarnya paragraf deduktif kalimat utamanya terletak di awal paragraf. Sedangkan paragraf induktif kalimat utamanya terletak di akhir paragraf. Menulis berita berarti mampu menguasai unsur-unsur yang terdapat di dalam berita tersebut. Menguasai berarti mampu menemukan setiap unsur-unsur yang mendasari sebuah berita. Menentukan unsur-unsur dalam berita yang merupakan prinsip dari $5 \mathrm{~W}+1 \mathrm{H}$ yang merupakan langkah penting yang dilakukan dalam menulis berita. Apa yang terjadi, Siapa yang menjadi tokoh (pelaku atau korban), Kapan peristiwa itu terjadi, Dimana terjadinya, Mengapa peristiwa itu terjadi, dan Bagaimana penyelesaian dari berita tersebut.

Kemampuan siswa dalam membedakan paragraf deduktif dan paragraf induktif memiliki hubungan yang positif dan signifikan dengan kemampuan menulis berita, hal ini dibuktikan dengan koefisien korelasi yang tinggi yaitu 0.380 dan besar sumbangan Kemampuan membedakan paragraf deduktif dan paragraf induktif $38 \%$ terhadap kemampuan menulis berita. Hal ini menunjukkan bahwa kemampuan membedakan paragraf deduktif dan paragraf induktif merupakan alternatif yang perlu diperhatikan dalam meningkatkan kemampuan menulis berita.

\section{PENUTUP}

Berdasarkan hasil penelitian yang telah diuraikan pada Bab IV, maka dapat dibuat kesimpulan di bawah ini: 
1. Tingkat Kemampuan membedakan paragraf deduktif dan paragraf induktif siswa kelas X Madrasah Aliyah Muhammadiyah 1 Medan tahun pembelajaran 2016/2017, tergolong cukup dengan nilai rata-rata sebesar 64,75 dan standar deviasi sebesar 8,04.

2. Tingkat kemampuan menulis berita siswa kelas X Madrasah Aliyah Muhammadiyah 1 Medan tahun pembelajaran 2016/2017, tergolong cukup dengan nilai rata-rata sebesar 68.03 dan standar deviasi sebesar 8,24.

3. Hubungan antara kemampuan membedakan paragraf deduktif dan paragraf induktif dengan kemampuan menulis berita siswa kelas X Madrasah Aliyah Muhammadiyah 1 Medan tahun pembelajaran 2016/2017 bersifat positif dan sangat signifikan dengan koefisien korelasi sebesar 0.380. Dengan demikian semakin tinggi kemampuan membedakan paragraf deduktif dan paragraf induktif semakin tinggi pula tingkat kemampuan menulis berita.

\section{DAFTAR PUSTAKA}

Arikunto, Suharsini. 2006 Prosedur Penelitian Suatu Pendekatan Praktek. Jakarta: Rineka Cipta.

Atmazaki. 2007. Pengembagan Paragraf. Bandung.

Barus, sanggup. 2010. Pembinaan Kompetensi Menulis. Medan:USU press.

Tarigan. 2008. Membina Keterampilan Menulis Paragraf dan Pengembangannya. Bandung: Angkasa Bandung. 